ISSN: 0213-2087 eISSN: 2444-7080

DOI: http://dx.doi.org/10.14201/shhc201836197225

\title{
«TODOS SE CONSIDERAN CON DERECHO A REQUISAR...» REQUISICIONES E INCAUTACIONES DE BIENES EN GALICIA DURANTE LA GUERRA CIVIL*
}

\section{Everyone Consider Themselves Entitled to Requisition... Requisitions and Seizures of Property in Galicia During the Civil War}

\author{
Julio PRADA RODRÍGUEZ \\ Universidad de Vigo \\ jprada@uvigo.es
}

Recepción: 24/07/2017 Revisión: 22/04/2018 Aceptación: 25/05/2018

RESUMEN: En este artículo se analizan las requisas e incautaciones de bienes llevadas a cabo en Galicia durante los primeros meses de la guerra civil a partir de diversa documentación procedente de las Secciones de Estado Mayor de la División. En primer lugar, se estudia el marco normativo que les sirvió de soporte y las diferentes autoridades y entidades que se arrogaron el derecho de decretarlas, así como sus finalidades y los bienes objeto de las mismas. A continuación se indaga en los sujetos pasivos y se examinan las diferentes actitudes sociales de la población ante aquellas. Se concluye la ausencia de un descontrol generalizado en la retaguardia, compatible con la existencia de un cierto policentrismo inicial, así como la complejidad de las respuestas de la población, que abarcan desde las inquebrantables adhesiones hasta las formas de resistencia de baja intensidad.

Palabras clave: Requisas; Incautaciones; Actitudes sociales; Guerra Civil; Galicia.

* Este artículo se inscribe en las líneas de investigación abiertas en el seno del Proyecto de Investigación HAR2014-56846-P, del que el autor es investigador principal. 
ABSTRACT: This article analyses the requisition and seizures of property in Galicia during the first months of the civil war. First, there are studied the legislation and the authorities and entities that ordered those, his purpose and the seized goods. Later the passive subjects are studied and there are examined the different social attitudes of the population using documentation of the Staff Officer's Sections. We conclude that there is no generalized lack of control in the rear, compatible with the existence of a certain initial polycentrism, as well as the complexity of the people responses, including from unwavering supports to lower intensity resistance forms.

Key words: Requisition; Seizures; Social attitudes; Civil War; Galicia.

\section{INTRODUCCIÓN}

Los aspectos relacionados con la economía de guerra en la retaguardia sublevada no han recibido la misma atención historiográfica que otros apartados de la contienda civil. Ello no es óbice para que existan un buen número de estudios que han permitido avanzar de modo significativo en diferentes cuestiones ${ }^{1}$, a los que habría que sumar los centrados en determinados aspectos de la represión económica, en particular las responsabilidades civiles y políticas, sobre las que ya comienzan a aparecer trabajos que superan el marco provincial al que se habían ceñido las investigaciones surgidas desde la segunda mitad de los años noventa ${ }^{2}$. La mayoría de estas últimas, tanto las que analizaban la represión económica partiendo de la premisa de que el conjunto de la represión franquista no podía entenderse sino era adoptando un punto de vista amplio que fuese mucho más allá de la dimensión física, como las que se acercaban al tema de forma monográfica, apenas daban cabida en sus páginas al estudio de las requisas e incautaciones de bienes llevadas a cabo en la zona rebelde antes de la entrada en vigor del Decreto n. 108 de la Junta de Defensa Nacional, de 13 de septiembre de 1936, y, más tarde,

1. Prado Herrera, María Luz de: La contribución popular a la financiación de la Guerra Civil: Salamanca, 1936-1939. Salamanca: Ediciones de la Universidad de Salamanca, 2012 [libro electrónico], pp. 15-16; Ruz, Julius: La justicia de Franco. La represión en Madrid tras la Guerra Civil. Barcelona: RBA, 2013, p. 198; BARciela López, Carlos y López Ortiz, M. ${ }^{a}$ Inmaculada: "Una nación en crisis y dos economías enfrentadas. La historiografía económica de la guerra civil española», Studia Historica. Historia Contemporánea, 32, 2014, p. 198. Remitimos a este último artículo para un reciente estado de la cuestión sobre especialistas y líneas temáticas, en el que, muy significativamente, no aparecen mencionadas las palabras "requisas" ni "incautaciones».

2. Álvaro Dueñas, Manuel: "Por ministerio de la ley y voluntad del Caudillo»: La jurisdicción especial de responsabilidades políticas (1939-1945). Madrid: Centro de Estudios Políticos y Constitucionales, 2006; Casanova, Julián y Cenarro, Ángela (eds.): Pagar las culpas. La represión económica en Aragón (1936-1945). Barcelona: Crítica, 2014; Gómez Oliver, Miguel; MarTínez López, Fernando y BARRAGán, Antonio (coords.): El "botín de guerra» en Andalucía. Cultura represiva y víctimas de la Ley de Responsabilidades Politicas, 1936-1945. Madrid: Biblioteca Nueva, 2015; Prada Rodríguez, Julio: "Marcharon con todo". La represión económica en Galicia durante el primer franquismo. Madrid: Biblioteca Nueva, 2016. 
del Decreto Ley n. ${ }^{\circ} 157$ de 10 de enero de 1937 y la Orden de la misma fecha que lo desarrollaba ${ }^{3}$. No resulta infrecuente, incluso, que pillajes, rapiñas, incautaciones, requisas y confiscaciones, ya fueran practicadas directamente por el Ejército con más o menos formalidades ya por milicianos en nombre de su organización o por iniciativa particular, se entremezclen en sus páginas sin demasiado rigor analítico y sin el necesario esfuerzo para intentar sistematizar lo que son entidades y contextos difícilmente homologables.

A este hecho no han sido ajenas dos circunstancias que han lastrado hasta nuestros días este tipo de investigaciones. En primer lugar, las carencias documentales, imputables, al margen de las consabidas pérdidas que hubieran podido producirse, a un variado conjunto de razones entre las que se encuentran el relativo "descontrol» producido en la retaguardia durante los primeros meses de la guerra. La falta de una unidad de mando entre los rebeldes hizo, por ejemplo, que determinados generales intentasen consolidar una estructura de poder autónomo frente a la Junta de Defensa Nacional, llegando a legislar por su cuenta en materia de incautaciones de bienes ${ }^{4}$. La multiplicación de milicias y sus pretensiones de escapar del control directo de sus mandos naturales y de las propias autoridades militares también ha sido esgrimida de forma unánime para explicar estas lagunas, sobre todo por el interés de sus miembros de no dejar rastro alguno de sus extorsiones cuando se habían perpetrado al margen de los conductos oficiales. Y, por último, las perentorias necesidades de asegurar, primero, el control del territorio y, más tarde, la atención a los frentes bélicos, cuyas necesidades exigían celeridad y eficacia antes que registros y comprobaciones.

3. SÁnchez Recio, Glicerio: Las responsabilidades políticas en la posguerra española. El partido judicial de Monóvar. Alcoy: Secretariado de Publicaciones de la Universidad de Alicante, 1984; Mir, Conxita et al.: Repressió econòmica y franquisme. El tribunal de Responsabilitats Polítiques a la província de Lleida. Barcelona: Publicaciones de l'Abadía de Montserrat, 1997; Granja Fernández, Pilar de la: Represión durante la guerra civil y la posguerra en la provincia de Zamora. De los consejos de guerra al Tribunal de Responsabilidades Políticas en el partido judicial de Puebla de Sanabria (1936-1945). Zamora: Instituto de Estudios Zamoranos "Florián de Ocampo", 2002; PRADA RoDríGUEZ, Julio: Represión económica e depuración administrativa. Ourense 1936-1942. Ourense: Obradoiro de Historia de Galicia, 2003; Franco Lanao, Elena: Denuncias y represión en años de posguerra. El Tribunal de Responsabilidades Políticas en Huesca. Huesca: Instituto de Estudios Altoaragoneses, 2005; SANLLoRente, Francisco: La persecución económica de los derrotados. El Tribunal de Responsabilidades Politicas de Baleares (1939-1942). Mallorca: Miquel Font Editor, 2005; GIL BASTERRA, Iñaki: Jurisdicción especial y represión franquista en Álava (1936-1942). Documentación del Tribunal de Responsabilidades Políticas para Álava. Vitoria: Servicio Central de Publicaciones del Gobierno Vasco, 2006; Barragán Moriana, Antonio: Control social y responsabilidades políticas. Córdoba (1936-1945). Córdoba: Editorial el Páramo, 2009; Peña Rambla, Fernando: El precio de la derrota la Ley de responsabilidades políticas en Castellón, 19391945. Castellón de la Plana: Universitat Jaume I, 2009.

4. El mejor ejemplo en esta materia lo constituye Queipo de Llano como puede verse en BARRAGÁn MoRiana, Antonio: “Todo por la patria! Incautación de bienes, rapiña bélica y suscripciones populares para el bando rebelde». En: Gómez Oliver, Miguel; Martínez López, Fernando y Barragán, Antonio (coords.): El «botín de guerra» en Andalucía..., op. cit., pp. 39 y ss. 
En segundo lugar, las dificultades objetivas para deslindar unas y otras, pues, con cierta frecuencia, la documentación emplea de forma indistinta términos que se refieren a realidades diversas cuando no acredita que se llevaron a cabo esgrimiendo un título y unos preceptos que no eran los más adecuados para el caso. Algo a lo que, al margen de la coyuntura bélica, tampoco debió de ser ajeno el hecho de que hasta la Ley de Expropiación Forzosa de 1954 las diferentes figuras expropiatorias surgieron y se regularon de forma autónoma e independiente, cada una con su propia naturaleza y régimen jurídico peculiar ${ }^{5}$. Ello no es obstáculo para ver en las requisas militares una forma de ocupación temporal que desde la Ley de 10 de enero de 1879 y el Reglamento que la desarrollaba aparece configurada como una servidumbre pública, calificación que mantendrían los Reglamentos de aplicación de la misma a los ramos de Guerra y Marina en tiempo de paz La normativa posterior que regulaba el derecho de requisición tanto para tiempo de guerra como de paz, a la que enseguida nos referiremos, configura la requisa como una figura compleja que se distinguiría de otras figuras expropiatorias tanto por su causa legitimadora como por el procedimiento sumario y expeditivo mediante el cual los legitimados para practicarla adquieren la posesión de los bienes sometidos a la misma.

A ello habría que añadir la imposibilidad práctica de encontrar un criterio plenamente satisfactorio que conjugue la precisión conceptual con el rigor a la hora de determinar la autoridad de la que emana una orden de requisición o de incautación de un determinado bien. Distinguir, por ejemplo, entre regladas y no regladas en función de que se haya aplicado o no la prolija normativa existente en la materia al producirse el golpe, los bandos de guerra o las nuevas pautas de actuación de que se fueron dotando los sublevados resulta ilusorio teniendo en cuenta que durante esos primeros meses, con frecuencia, las autoridades no se preocuparon de esgrimir principio alguno que no fueran los de necesidad e inmediatez y, sobre todo, que de un porcentaje imposible de estimar de las mismas no se levantaron actas ni arqueos. Diferenciar de las no regladas entre "legalizables" y «no legalizables» en función de que hayan sido reconocidas o no por las autoridades militares, restringiendo las últimas a las perpetradas por las milicias sin orden expresa de aquellas, no deja de ser una forma de pasar por alto el hecho de que dichas jerarquías las consintieron cuando no las alentaron con desigual intensidad y duración dependiendo de cada zona geográfica.

5. Escribano Collado, Pedro, "Ocupación temporal», Revista de Administración Pública, 106, enero-abril-1985, p. 57.

6. Ley de Expropiación Forzosa, Gaceta de Madrid, n. ${ }^{\circ} 12$ de 12/01/1879, pp. 105-107; Real Decreto por el que se aprueba el reglamento para la ejecución de la ley de expropiación forzosa, Gaceta de Madrid, n. 175 de 24/06/1879, p. 846; Real Decreto por el que se aprueba el reglamento para la aplicación al ramo de Guerra en tiempo de paz de la ley de 10 de Enero de 1879 sobre expropiación forzosa, Gaceta de Madrid, n. 78 de 19/03/1881, p. 749; y Real Decreto por el que se aprueba el reglamento para el cumplimiento de la ley de Expropiación forzosa en lo que tenga relación con las defensas del Reino, acuartelamiento y edificios de Marina, Gaceta de Madrid, n. ${ }^{\circ} 60$ de 01/03/1891, p. 652. 
El territorio de la antigua Octava División Orgánica, en el que se encuadraban Galicia, León y la Comandancia Exenta de Asturias al producirse el golpe de Estado, no es una excepción en cuanto a los problemas apuntados. A pesar de ello se conserva una masa documental bastante significativa en las Secciones de Estado Mayor del Archivo Intermedio Militar Noroeste (AIMN), a la que hay que unir contados documentos en algunos antiguos Gobiernos Militares (actuales Subdelegaciones de Defensa) e informaciones dispersas tanto en causas militares como expedientes de responsabilidades civiles y políticas que, convenientemente cruzadas con las bases de datos elaboradas por los diferentes investigadores que se han adentrado en el estudio de la represión en esta comunidad autónoma ${ }^{7}$, permiten realizar un análisis que supera la mera dimensión descriptiva y cuantitativa de requisiciones e incautaciones para introducir una perspectiva social que resulta muy enriquecedora.

A través de su análisis podemos acercarnos, en efecto, al complejo problema de las actitudes sociales ante el régimen en proceso de construcción, a sus apoyos y a las resistencias que encontró entre la población, a las disputas surgidas entre grupos afines por su control o a su utilización para castigar el compromiso o la mera simpatía con el proyecto político republicano y a la vez coadyuvar a la generación de lealtades en sectores de lo más diverso. Nos permiten, en definitiva, profundizar en los fenómenos sociales que engendró el hecho mismo de la guerra, descubrir los entresijos de las relaciones entre sociedad civil y militares rebeldes ${ }^{8}$ y con ello poner en evidencia como cada ser humano era protagonista de su propia historia en aquellas difíciles circunstancias?. Tales son los objetivos fundamentales que nos proponemos en este trabajo, limitando nuestra investigación a las requisas e incautaciones llevadas a cabo en el ámbito geográfico de Galicia por el Ejército al margen de la normativa específica de responsabilidades civiles y políticas, cuyo examen requiere de una metodología y un enfoque diferente del aquí propuesto. Para ello comenzaremos con un somero repaso del marco normativo empleado para llevarlas a cabo que sirva para enmarcar la actuación de las diferentes autoridades y entidades que se arrogaron el derecho de decretarlas, deteniéndonos, asimismo, en sus finalidades y en los bienes objeto de las mismas. Examinaremos, a continuación, los sujetos pasivos afectados y remataremos con un apartado destinado a analizar las respuestas de los sectores implicados a partir de la documentación conservada.

7. Una parte de dichos datos pueden consultarse en http://vitimas.nomesevoces.net/, https:// www.depourense.es/represion/ y http://www.lugo.es/cs/represion/index.jsp.

8. Aróstegui, Julio: «Los componentes sociales y políticos». En: TuÑón de Lara, Manuel et al.: La guerra civil 50 años después. Barcelona: Labor, 1985, p. 93; CuEsta Bustillo, Josefina: "La guerra civil y la militarización del espacio en Salamanca (1936-1939)», Salamanca. Revista de Estudios. Las guerras en Salamanca. SS. XVII-XX, 40, 1997, p. 404.

9. LÜDTKE, Alf: "De los héroes de la resistencia a los coautores. Alltagsgeschichte en Alemania", Ayer, 19, 1995, pp. 49-50. 
2. LAS PERENTORIAS CIRCUNSTANCIAS DEL MOMENTO EXIGÍAN, ANTE TODO, ASEGURAR EL SERVICIO RECLAMAdO POR EL MANDO...

El 4 de septiembre de 1936, el presidente de la Junta de Defensa Nacional, Miguel Cabanellas Ferrer, firmaba el Decreto n. 85 por el que se disponía el nombramiento del coronel Miguel Gallego Ramos como Intendente general de los Ejércitos de España en operaciones, fijando además su residencia en Burgos ${ }^{10}$. Tres días más tarde, coincidiendo con la publicación de su nuevo empleo en el BOJDN, dictó una circular conteniendo una serie de instrucciones destinadas a unificar los Servicios de Intendencia en la zona controlada por los sublevados. En ella admitía que existían una serie de apartados, en particular el de transporte, en los que "más se deja sentir la precipitación, inevitable en los primeros momentos, en los cuales todos se consideran con derecho a requisar, sin meditar bien el límite que ha de ponerse a tan costoso servicio" ${ }^{11}$. Semejante afirmación no era sino el reconocimiento explícito de lo que hasta entonces había venido ocurriendo en las diferentes provincias controladas por los rebeldes. En ellas, la perentoria necesidad de asegurar los distintos servicios que demandaba la nueva coyuntura, el cierto policentrismo creado por las "circunstancias actuales» a las que se refería el Intendente y la aparición de nuevos actores, en particular las diferentes milicias, habían trastocado las, hasta entonces, rígidas y burocráticas normas por las que se regía el Ejército en materia de requisas e incautaciones ${ }^{12}$.

La normativa vigente reconocía el derecho de requisición a la Autoridad militar competente (Ministro de la Guerra, General en Jefe del Ejército, Comandantes Generales de Ejército, Cuerpo de Ejército y Región y Jefes de divisiones, brigadas

10. Boletín Oficial de la Junta de Defensa Nacional (BOJDN), n. ${ }^{\circ} 17$ de 7/09/1936, p. 2. Una breve biografía del mismo con ocasión de su ascenso a coronel de Intendencia en Gaceta de Madrid, n. ${ }^{\circ} 271$ de 28/09/1935, p. 2.410; su nombramiento como Intendente General y como Inspector de los Servicios de Intendencia de la segunda Inspección General a propuesta del ministro de la Guerra, José María Gil Robles, respectivamente, en Gaceta de Madrid, n. ${ }^{\circ} 270$ de 27/09/1935, p. 2.384 y n. ${ }^{\circ} 284$ de 11/10/1935, p. 223. Figura entre los cesados por Orden del Ministro de la Guerra de 16 de agosto de 1936 con el resto de los generales rebeldes.

11. AIMN, Sección Estado Mayor (SEM), n. ${ }^{\circ}$ 4, carpeta "Instrucciones para unificar los Servicios de Intendencia». La cursiva es nuestra.

12. Real Decreto autorizando al Ministro de la Guerra para que presente a las Cortes un proyecto de ley de Estadística y Requisición militar (Gaceta de Madrid, n. ${ }^{\circ} 313$, de 09/11/1915, pp. 297 a 298); Real Decreto de Estadística y Requisición de 1 de diciembre de 1917 (Gaceta de Madrid, n. ${ }^{\circ} 336$, de 2/12/1917, pp. 473-476); Real Decreto aprobando las bases que se publican para la reorganización del Ejército (Gaceta de Madrid, n. ${ }^{\circ}$ 69, de 10/03/1918, pp. 702 a 714); Real Decreto autorizando al Ministro de Guerra para presentar a las Cortes un proyecto de ley aprobando las bases para la reorganización del Ejército, así como lo dispuesto en el de $1^{\circ}$ de diciembre de 1917 acerca de los servicios de Requisición y Estadística (Gaceta de Madrid, n. ${ }^{\circ}$ 123, de 03/05/1918, pp. 322 a 324); Ley de 29 de junio de 1918 aprobando las Bases para la reorganización del Ejército contenidas en el Real Decreto de 7 de marzo de 1918 (Gaceta de Madrid, n. ${ }^{\circ}$ 181, de 30/06/1918, pp. 823-841); Reglamento de Estadística y Requisición para la aplicación del anexo n. ${ }^{\circ} 3$ de la Ley de 29 de junio de 1918 (C. L. n. ${ }^{\circ} 169$ ) aprobado por Real Orden Circular de 13 de enero de 1921 (Gaceta de Madrid, n. ${ }^{\circ}$ 273, de 25/08/1921, pp. 808-822). 
y otros núcleos de fuerzas en misión espacial), con facultad de delegar su ejercicio en los Jefes y Oficiales del Cuerpo de Intendencia Militar y, en su defecto, en los comandantes de tropas destacadas, los cuales, a su vez, podían subdelegarla en personal a sus órdenes ${ }^{13}$. Toda prestación daba derecho a indemnización del servicio prestado o del valor objetivo de lo requisado, salvo en los casos explícitamente determinados. Se consideraban requisitos indispensables a toda requisición una orden previa escrita, puntualizando la clase y cuantía de la prestación y, siempre que fue posible, la duración del servicio reclamado, y un recibo inmediato de la misma ${ }^{14}$.

En tiempo de guerra, con las limitaciones y excepciones previstas, se recogía un amplio catálogo de prestaciones requisables, entre las que figuraban las de personas que por razón de profesión u oficio pudieran servir de auxiliares a las tropas o sus servicios, ganado de silla, tiro y carga, vehículos de tracción animal, automóviles, embarcaciones, máquinas, herramientas, utensilios y material de cualquier clase; elementos para alumbrado, combustible, grasas, toda clase de energía eléctrica cualquiera que fuese el modo de producción, metales, medicamentos, productos químicos necesarios para la industria de guerra, etc. También estaba contemplada la ocupación temporal o definitiva de propiedades rústicas y urbanas, casas y edificios públicos para alojamiento de tropas o almacenamiento del material, fábricas, talleres, minas, establecimientos industriales, material, existencias, materias primas, reses y demás productos de consumo necesarios para la alimentación de hombres y ganado, municiones, armas, efectos de vestuario, ferrocarriles, tranvías, medios de comunicación, etc. ${ }^{15}$. Para la valoración de las prestaciones exigidas por vía de requisición, debían constituirse una Comisión central y las provinciales y especiales que fuera menester, correspondiendo a las provinciales señalar precios a las prestaciones en las que no hubiese recaído tarificación general, elevando sus relaciones para aprobación de la central ${ }^{16}$.

El Decreto n. ${ }^{\circ} 14$ de 28 de julio de 1936 hizo extensiva la declaración del Estado de guerra en todas las provincias a la vez que el bando disponía en su artículo 8 la incautación de "todos los vehículos y medios de comunicación de cualquier clase ${ }^{17}$. A esta disposición seguirían otras varias a lo largo del mes de agosto que ponían de manifiesto la improvisación existente en esta materia ${ }^{18}$. La creación

13. Real Decreto de Estadística y Requisición de 1 de diciembre de 1917 (art. 1), al que dio fuerza de Ley la de 29 de junio de 1918 aprobando las Bases para la reorganización del Ejército, reproduciéndolo en su anexo n. ${ }^{\circ}$, y Reglamento de Estadística y Requisición aprobado por Real Orden Circular de 13 de enero de 1921 (arts. 1, 2 y 4).

14. Real Decreto de 1 de diciembre de 1917 (arts. 2 y 4).

15. Real Decreto de 1 de diciembre de 1917 (art. 6).

16. Real Decreto de 1 de diciembre de 1917 (arts. 40, 41 y 43). Vid., asimismo, los arts. 137 y ss. del Reglamento de Estadística y Requisición de 1921.

17. BOJDN, n. ${ }^{\circ} 3$, de 30/07/1936, pp. 9-11.

18. Orden de 3 de agosto de 1936 ordenando a las Autoridades de Marina de Ferrol la incautación transitoria de los talleres y dependencias de la Sociedad Española de Construcción naval y la 
de la mencionada Intendencia General representó un esfuerzo en la dirección de conferir una cierta unidad a los diferentes Servicios de Intendencia, pero lo cierto es que su alcance fue bastante limitado. Como su propio titular admitía, dicho organismo, "sin enlace con las Oficinas Centrales y con 2 Jefes y 1 Auxiliar por todo el personal [...], ha de limitarse a marcar directrices generales y llevar la alta dirección de los servicios, pero sin constituir una rueda más que entorpezca [...]. Por ello, la gran mayoría de los asuntos deberían continuar resolviéndose dentro del marco de las Divisiones, siendo por lo tanto las respectivas Intendencias las llamadas a resolver, «recabando la aprobación del General [cuando] sea necesario y acudiendo a esta Intendencia General solamente en casos especiales». La norma primordial a la que debían ajustarse aquellas era la de «dar al Mando toda clases de facilidades, procurando en primer término asegurar el servicio y después que ello se verifique en las condiciones menos onerosas para el Estado, pues si en todo tiempo y lugar tenemos la obligación de velar por los intereses del Tesoro, en las circunstancias actuales ese deber se acrecienta notablemente ${ }^{19}$.

La Circular del coronel Gallego insistía en que debía procurarse realizar siempre las compras de la forma ordinaria, «recurriendo a la requisición o incautación solamente cuando sea indispensable». Asimismo, contenía diversos apartados relativos a la composición de las Comisiones de Requisición y dictaba una serie normas para la adquisición y reparto de subsistencias a las que no eran ajenas el descontento que comenzaba a percibirse en determinadas unidades conforme se desprende de un revelador párrafo en el que también se alude a la inveterada tendencia de las regiones, provincias y aun comarcas de pretender que sus auxilios beneficiasen únicamente a sus naturales:

Van siendo muy frecuentes las quejas de quienes estiman no le llegan aquellos [suministros] en la debida proporción; por ello se recomienda muy insistentemente

\begin{abstract}
movilización de su personal (BOJDN, n. ${ }^{\circ} 4$ de 04/08/1936, p. 15); Orden de 20 de agosto de 1936 ordenando a los Gobernadores Civiles que procedan a la incautación de aquellos trigos propiedad del Estado que vayan destinados a Provincias o lugares no sometidos a la JDN (BOJDN, n. 9 de 21/08/1936, p. 36); Decreto n. ${ }^{\circ} 38$ dictando reglas para la incautación provisional de los establecimientos fabriles, bienes inmuebles, valores, etc., de la Sociedad Anónima "Industrias Agrícolas» (BOJDN, n. ${ }^{\circ} 7$ de 17/08/1936, pp. 25-26); Decreto n. ${ }^{\circ} 41$ de 16 de agosto de 1936 dictando reglas para la incautación provisional de depósitos, almacenes o establecimientos de la razón social "Busquets Hermanos y Compañía" (BOJDN, n. ${ }^{\circ} 7$ de 17/08/1936, p. 27); Decreto n. 63 de 24 de agosto de 1936 dictando reglas para la incautación provisional de Nujol, Mistol, Gets, aceite de ricino «El Goloso» y demás productos medicinales de la razón social "Busquets Hermanos y Compañía" (BOJDN, n. ${ }^{\circ} 11$ de 25/08/1936, pp. 41-42); Decreto n. $^{\circ} 70$ de 27 de agosto de 1936 facultando a los Generales en Jefe de los Ejércitos en campaña para proponer las incautaciones de minerales y sus derivados y de los productos procedentes de transformaciones industriales (BOJDN, n. ${ }^{\circ} 13$ de 29/08/1936, p. 49); Decreto n. ${ }^{\circ} 75$ dictando reglas para la incautación provisional de todos los establecimientos fabriles, bienes inmuebles, muebles, valores, etc., de la Sociedad Anónima "Banco Agrícola Comercial» (BOJDN, n. ${ }^{\circ} 14$ de 30/08/1936, pp. 54-55); Decreto n. 78 dictando reglas para la incautación provisional de todos los establecimientos fabriles, bienes inmuebles, muebles, valores, etc., de la razón social "López Hermanos y Compañía» (BOJD, n. ${ }^{\circ} 15$ de 04/09/1936, pp. 57-58).

19. AIMN, SEM, n. ${ }^{\circ} 4$, carpeta "Instrucciones para unificar los Servicios de Intendencia».
\end{abstract}


que no se haga distribución alguna por la exclusiva iniciativa de quien tenga a su cargo el Depósito, sino que todo se verifique de acuerdo con el Mando, procurando la mayor equidad en el reparto. Como esas quejas pudieran ser en parte motivadas por el deseo de algunas regiones que quieren que sus donativos los disfruten únicamente sus paisanos, es muy conveniente no perdure este criterio; lo que exista en los Depósitos debe ser para todos ${ }^{20}$.

No menos explícita era su velada alusión a las requisas, sobre todo de automóviles, que se estaban llevando a cabo en toda la retaguardia sublevada al margen del Ejército e incluso de las autoridades militares provinciales. Conforme a sus instrucciones, las Jefaturas de Transportes deberían investigar cuanto antes todas aquellas requisiciones realizas sin su intervención, determinando quiénes y con qué autoridad las habían verificado, y obtener de la autoridad competente las órdenes correspondientes. A los propietarios de los vehículos requisados debería entregárseles el documento que habría de servirles de base para la liquidación, correspondiendo a las Pagadurías de Transportes de la plaza correspondiente la reclamación y pago de devengos del personal afecto a aquellos. "No se tomará en consideración -remataba el Intendente- los coches requisados o apropiados por personas a todas luces incompetentes para tomarse estas atribuciones, dejando a los que lo verificaran la responsabilidad de sus actos ${ }^{21}$.

Pero, ¿quiénes eran esas personas incompetentes que se arrogaban la facultad de requisar diferentes bienes? ¿A qué autoridades se refería el Intendente cuando afirmaba que todos se consideraban con derecho a requisar? Con excepción de las requisiciones en las que intervenían los Servicios de Intendencia de la 8. ${ }^{a}$ División Orgánica, que eran reglamentariamente puestas en conocimiento y sometidas a la autorización del general al mando, lo más común fue que durante los primeros meses los diferentes comandantes militares, delegados de Orden Público y gobernadores civiles las decretasen sin haber recibido delegación expresa de aquel, a veces mediante simples órdenes verbales.

Entre los que recurrieron a tan expeditivo método destaca el comandante militar de Vigo, el teniente coronel Felipe Sánchez Rodríguez, quien decretó la requisa de gran número de edificios para alojamiento de tropas e instalación de hospitales sin informar a las autoridades de la División ni, en la mayoría de los casos, a su superior provincial. Dicho mando, si bien no vaciló a la hora de incautarse de muebles e inmuebles de izquierdistas más o menos significados, tampoco mostró excesivos miramientos con los bienes propiedad de la Iglesia o de comunidades religiosas. Así, en julio de 1938, el superior de los Maristas, Antonio Álvarez Saiz, se quejaba amargamente en un escrito al general jefe de la 8. ${ }^{a}$ Región dando cuenta que el Colegio que poseían en la ciudad olívica fue requisado por primera vez entre el 8 de agosto de 1936 y el 8 de septiembre de 1937, fecha en la que hubieron

20. Ibidem.

21. Ibidem. La cursiva es nuestra. 
de regresar por orden de la Comandancia. Ya hechas las reparaciones pertinentes causadas por las tropas acuarteladas, una nueva orden verbal de marzo de 1938 obligó a desalojarlo de nuevo en el plazo de 48 horas, considerando que si bien la primera fue necesaria por la incorporación inminente de los reclutas, no así la segunda, por lo que «la Jefatura de Estado Mayor de Coruña, que siempre veló por evitar el mayor daño posible, envió a la Comandancia de Vigo el 24 de marzo un telegrama autorizando la requisa del Colegio y ordenando que al mismo tiempo se facilitara otro local. Esta orden no fue cumplidan, por lo que la Comunidad se vio obligada a arrendar otro local y con ello terminar el curso ${ }^{22}$.

En otras ocasiones intervenían mandos militares que se limitaban a transmitir sus exigencias a los afectados sin entregar documento alguno y sin siquiera ponerlo en conocimiento de sus superiores. Fue lo que ocurrió, por ejemplo, con el almacén del comerciante Emilio Zaera Vázquez (Sarria, Lugo), al que dos jefes del Ejército no identificados le notificaron su requisa para alojamiento de tropas sin que, pasados los meses, volviera a tener noticia de los mismos. El 8 de noviembre de 1938, el teniente coronel jefe del Servicio de Requisa de la 8. ${ }^{a}$ Región Militar reconocía que,

[...] pedidos antecedentes a la Delegación de Requisa de Lugo, me manifiesta que no obra dato alguno sobre el local del recurrente. [...] habiéndose emitido informe en el sentido que se ignoraba en virtud de qué orden los dos Jefes del Ejército a que el recurrente se refiere, habían notificado la requisa del local $[\ldots]^{23}$.

En Pontevedra, la Residencia de Estudiantes fue ocupada por fuerzas del Regimiento de Artillería n. ${ }^{\circ} 29$ al resultar insuficiente el acuartelamiento sin siquiera intervención del gobernador militar de la provincia, que reconocía que carecía de cualquier noticia sobre dicha requisa, aunque «según datos adquiridos el mencionado edificio fue ocupado al principio del Glorioso Movimiento Nacional por fuerzas del Ejército por estar deshabitado [...] ${ }^{24}$.

Pero fueron las secciones locales de FE-JONS las que llevaron a cabo más requisas sin otro amparo ni mandamiento que la ostentación de un uniforme al que las perentorias circunstancias del momento conferían un poder casi omnímodo, en especial en los ámbitos rurales, donde no encontraban otro contrapeso que los comandantes de puesto de la Guardia Civil. En la mayoría de los casos, el cuadro no debió de diferir mucho del esbozado por Ramón Fernández García (Taboada,

22. AIMN, SEM n. ${ }^{\circ}$ 4, carpeta «Expedientes de requisas y devoluciones de edificios en la provincia de Pontevedra (1936-1945)", 38. Tanto el gobernador militar de Pontevedra como la Jefatura de los Servicios de Requisa del Cuerpo de Ejército afirmaron carecer de antecedentes relativos a dicha requisa, limitándose el comandante militar de Vigo a informar en el sentido de que se decretó por orden directa de su autoridad al carecer de locales adecuados en la plaza para acoger a los contingentes movilizados.

23. AIMN, SEM n. ${ }^{\circ} 4$, carpeta "Expedientes de requisa de edificios de la provincia de Lugo (1936-1945)", 28

24. AIMN, SEM n. ${ }^{\circ}$, carpeta "Expedientes de requisas y devoluciones de edificios en la provincia de Pontevedra (1936-1945)», 3. 
JULIO PRADA RODRÍGUEZ

«TODOS SE CONSIDERAN CON DERECHO A REQUISAR...» REQUISICIONES

E INCAUTACIONES DE BIENES EN GALICIA DURANTE LA GUERRA CIVIL

Lugo) en su escrito dirigido al general jefe del 8. Cuerpo de Ejército, donde aseguraba que

[...] el día 31 de agosto de 1936, el entonces Jefe local de Falange Española D. Jesús Álvarez Somoza en unión del Sacerdote D. Ramón Serrapio Gil y del vecino de este término D. Ramón Fente Serrapio exigió al exponente le entregase las llaves del salón que ocupa la casa propiedad del que suscribe [...] y entregadas que le fueron las expresadas llaves, se instaló en el referido salón el Cuartel de Falange de este pueblo. Que desde entonces y a pesar de haber solicitado verbalmente del Sr. Jefe de Falange el abono del alquiler correspondiente al mencionado inmueble, es hoy el día que no se ha satisfecho cantidad alguna por el expresado concepto, ni se le ha dado una contestación categórica sobre el particular [desconociendo el recurrente] si se halla sujeto a requisa y si para ello precedió la oportuna orden de la autoridad correspondiente ${ }^{25}$.

No parece haber sido esta la tónica general en las principales ciudades ni en aquellas villas en las que los comandantes militares tenían a su cargo contingentes de tropa o de la Guardia Civil significativos debido a la presencia cercana de grupos de huidos o por su proximidad a centros estratégicos de comunicaciones. En estos casos lo más frecuente era que los responsables de las diferentes organizaciones políticas y milicias que se habían sumado al golpe recabasen directamente el auxilio de aquellos, cuando los consideraban en disposición favorable para atender sus demandas, o se dirigiesen a sus mandos provinciales o regionales para que estos intercedieran ante los gobernadores militares o directamente ante la Jefatura de la División, bien para autorizar la ocupación bien para legitimarla.

En Vigo, por ejemplo, la delegación de FE-JONS, tras recabar autorización del comandante militar de la plaza, se incautó a los pocos días del golpe de la Casa del Pueblo y de un solar colindante donde instalaron las oficinas de la jefatura local y el cuartel general de sus milicias. No fue hasta el 30 de enero de 1937 cuando el jefe territorial de Galicia solicitó del general-jefe que «se legitime de manera concluyente el derecho de nuestra organización a ocupar provisionalmente [dichos inmuebles]». Tras el informe del auditor de guerra en el sentido de que correspondía resolver sobre la cuestión a la Comisión Central de Incautación de Bienes, la autoridad militar, a la espera de que aquella decidiese, autorizó que FE-JONS mantuviese el usufructo del inmueble "por los méritos notoriamente contraídos ante la Patria por F.E., heraldo primero de nuestro sagrado Movimiento Nacional, [...] y ser la colaboradora más fiel, asidua y entusiasta de la acción de las armas nacionales en los frentes de combate y en la retaguardia ${ }^{26}$. No quisiéramos, con todo, transmitir en exceso la imagen de un descontrol, siquiera relativo, generalizado por toda la retaguardia. La Intendencia Militar de la División, a pesar de la situación creada por

25. AIMN, SEM n. ${ }^{\circ}$ 4, carpeta "Expedientes de requisa de edificios de la provincia de Lugo (19361945)», 20.

26. AIMN, SEM n. ${ }^{\circ}$, carpeta "Incautaciones", 28. 
el golpe de Estado en Galicia, siguió funcionando con relativa normalidad incluso durante los primeros momentos, procurando, como después dictarán las instrucciones del coronel Gallego, recurrir a las requisas solo cuando no fuese posible realizar compras ordinarias. Así, solo nueve días después de declarado el estado de guerra, y para atender las necesidades derivadas de la movilización de tropas, el Estado Mayor de la División reclamó la adquisición "con la mayor urgencia de 2.000 mantas de calidad y demás características de la mayor analogía posible dentro de la urgencia con las reglamentarias", calificando de perentoria la adquisición de al menos mil. En menos de veinticuatro horas, tras sendas reuniones de la junta técnica y la junta económica del Parque de Intendencia de A Coruña, y a pesar de que «no han sido halladas en el comercio local mantas que reúnan exacta ni aproximadamente las condiciones y características de la manta militar», se había puesto a disposición de aquel exactamente el millar solicitado tras una compra masiva a los Almacenes "Hijos de Simeón García y Cía." por importe de 15.455 pesetas, a lo que habría que sumar los más de 3.723 metros de lienzo destinados a la confección ochocientos jergones y quinientos cabezales de cama de tropa encargados al industrial colchonero Bonifacio Justo ${ }^{27}$.

También fueron muchos los inmuebles que se requisaron con todas las formalidades e incluso se abonaron los alquileres correspondientes desde el momento en que se llevaron a efecto. Por el chalet propiedad de Enriqueta Magadán que ocupaba el Gobierno Militar de Lugo se abonaba a su propietaria una renta de 400 pesetas mensuales, corriendo del Ejército la instalación de la calefacción y diversas obras. Los Talleres Mecánicos propiedad de José Sal Armas de la Ronda de Sanjurjo permanecieron requisados veinte meses en distintas fechas de 1937 y 1938 para el Servicio de Recuperación de Automóviles, acordándose un pago de 150 pesetas mensuales en concepto de alquiler sin que surtiese efecto el intento de las autoridades de que le fuese condonado, "por tratarse de una pobre viuda que no cuenta con más sustento que el que le proporciona el alquiler de dicho local", mientras que en el caso del Taller de Electricidad de Ladislao Klein se abonaban 100 pesetas mensuales y dos mecánicos a nueve pesetas diarias. No obstante, lo más frecuente fue que los propietarios que se atrevieron a solicitar el pago de los arrendamientos recibieran por toda contestación, hasta tiempo después de finalizada la guerra, que no era posible atender su petición "por no existir actualmente crédito alguno para pago de las requisiciones, ni autorizado por la Superioridad el funcionamiento de los organismos que entiendan en la valoración y reconocimiento de los respectivos derechos por ese concepto" 28 .

Otro tanto habría que decir en lo relativo a los medios de transporte, donde si bien se habían realizado numerosas requisas sin las formalidades exigidas, cuando

27. AIMN, SEM, Actas de la Junta Técnica y de la Junta Económica del Parque de Intendencia de A Coruña de 30/07/1936.

28. AIMN, SEM n. ${ }^{\circ}$ 4, carpeta "Expedientes de requisa de edificios de la provincia de Lugo (19361945)», 27. En el mismo sentido, ibidem, 5. 
no completamente irregulares, también existían abundantes ejemplos en sentido contrario. Las tempranas multas impuestas a propietarios de vehículos militarizados que no cumplían con alguna de las formalidades exigidas o que hacían uso de los mismos sin autorización demuestran, por ejemplo, el interés de la Jefatura de Requisa de A Coruña por ejercer un exhaustivo control sobre ellos así como por utilizar el importe de dichas sanciones para constituir un fondo para atenciones del servicio automovilístico e, incluso, para "premiar hechos relevantes de los conductores civiles o militares" ${ }^{29}$. Lo mismo ocurrió en lo que a las necesidades médicas y farmacéuticas se refiere: al lado de numerosas incautaciones de instrumental y medicamentos propiedad de profesionales conceptuados como simpatizantes del Frente Popular, también se realizaron abundantes compras por las vías ordinarias tanto en territorio español como portugués e, incluso, recurriendo a importadores autorizados, caso de Karl A. Vorkauf, con oficinas y almacenes en Lavadores (Vigo), que en su súplica a la División para que le fuesen abonadas las 1.243,40 pesetas de gasas y vendas «que fueron suministradas a la Octava División a precisos especiales con la condición de pago al contado» firmaba con un expresivo «AArriba España-Heil Hitler!»30.

Por otro lado, como en tantos otros aspectos, la prolongación de la guerra y los avances en la organización del nuevo Estado también se dejaron sentir en el ámbito de las requisas. Así, las disposiciones tendentes a garantizar un subsidio a aquellos propietarios de vehículos de transporte requisados cuando estos constituían su único medio de vida ${ }^{31}$ se vieron enseguida acompañadas por las destinadas a mitigar los desalojos de residentes en inmuebles incautados. En este sentido, si bien es cierto que desde los instantes iniciales del golpe se había procurado evitar la requisa de viviendas de particulares que estuvieran efectivamente ocupadas, ya fuese por sus propietarios o por sus arrendatarios ${ }^{32}$, lo cierto es que las "necesidades del mando" fueron repetidamente esgrimidas para justificar constantes excepciones. La Orden General del Ejército del Norte de 1 de junio de 1937 vino a decretar que en adelante no podría ser expulsado de su casa el ocupante de la vivienda (artículo 4) y, respecto a las viviendas desalquiladas, dispuso que «solo podrá disponer de tal medida Su Excelencia el General Jefe del Ejército del Norte, y los Gobernadores o Comandantes Militares que tienen delegación expresa para hacerlo»33. Dicha medida, si bien no eliminó por completo este tipo de requisiciones, es verdad que, al menos en Galicia, supuso una cierta inflexión respecto a los primeros meses con una significativa excepción: las zonas en las

29. Vid. AIMN, SEM n. ${ }^{\circ}$, carpeta "Multas impuestas por el jefe de Requisa de Esta Plaza" (1936)

30. AIMN, SEM n. ${ }^{\circ} 4$, carpeta "Medicamentos adquiridos en Portugal».

31. Boletín Oficial del Estado (BOE), n. ${ }^{\circ} 141$, de 10/03/1937, p. 652.

32. Incluso se dieron casos de requisas iniciales de inmuebles desocupados que fueron levantadas a solicitud de los propietarios una vez que se incorporaron a los mismos [vid., por ejemplo, AIMN, SEM n. ${ }^{\circ}$ 4, carpeta "Expedientes de requisa de edificios de la provincia de Lugo (1936-1945)», 18].

33. Citada en AIMN, SEM n. ${ }^{\circ} 4$, carpeta "Expedientes de requisa de edificios de la provincia de Lugo (1936-1945)», 18. 
JULIO PRADA RODRÍGUEZ

"TODOS SE CONSIDERAN CON DERECHO A REQUISAR..." REQUISICIONES

E INCAUTACIONES DE BIENES EN GALICIA DURANTE LA GUERRA CIVIL

que las grandes concentraciones de huidos obligaron a que, ya desde la primavera de 1937, las autoridades militares tuviesen que incrementar de forma sustancial los efectivos fijos y móviles de la Guardia Civil e incluso destinar soldados para incrementar el control y la vigilancia sobre los mismos. En estos casos, no fueron pocos los vecinos que continuaron teniendo que soportar durante años frecuentes desalojos, siquiera temporales, de sus viviendas para acomodar a los efectivos de las fuerzas del orden.

Con todo, hasta la entrada en vigor del Decreto de 9 de septiembre de 1939 no se produjo un giro radical en esta materia ${ }^{34}$. Esta disposición, por un lado, reiteraba la voluntad de continuar con la devolución de los bienes incautados "por las imperiosas necesidades de la guerra» a sus propietarios a la vez que prohibía nuevas requisas, incautaciones y ocupaciones de fincas rústicas y edificios y locales urbanos, salvo lo dispuesto en las leyes especiales. Por otro, ratificaba el derecho de requisición a la Autoridad Militar en los términos del Decreto de 1 de diciembre de 1917, del Reglamento de 13 de enero de 1921 y demás disposiciones concordantes. Asimismo, daba un mes de plazo para que todas las autoridades, organismos, centros, dependencias y oficinas, ya fuesen civiles o militares, entidades, organizaciones o personas, enviasen una detallada estadística de los bienes que todavía ocupaban en la que constasen los datos esenciales de los propietarios, la autoridad que dispuso la requisa, incautación u ocupación y las circunstancias que la determinaron, así como la justificación de la necesidad de mantenerlas total o parcialmente o, en su caso, de dejarlas sin efecto mediante la instalación de los servicios en otros inmuebles propiedad del Estado, la Provincia o el Municipio, debiendo informar la autoridad civil o militar competente sobre estos extremos.

Las autoridades militares de las Regiones y Departamentos y los Gobernadores Civiles deberían resolver, "con la mayor rapidez", sobre la legalidad de la requisa, incautación u ocupación, sobre su regularización o convalidación, así como sobre la necesidad de mantenerlas y sobre la instalación de los servicios en locales diferentes, pudiendo las partes interesadas reclamar sobre dichos acuerdos ante los Ministerios competentes en función de la autoridad que los dictara. Se trataba con ello de garantizar que los organismos castrenses quedasen instalados en edificios públicos para lograr el levantamiento del mayor número de requisas, ya que en caso de mantenimiento o convalidación de las requisiciones el organismo o entidad que los ocupare contraía la obligación de abonar la indemnización fijada de común acuerdo con el dueño, poseedor o arrendatario o, en su defecto, la que fijase el gobernador civil. Los inmuebles desalojados total o parcialmente, deberían ser puestos a disposición de sus dueños, levantando el acta correspondiente.

Como consecuencia, las solicitudes de devolución de inmuebles requisados u ocupados o, en su defecto, el abono de los alquileres correspondientes, se multiplicaron de forma exponencial a lo largo de los meses siguientes en toda Galicia, según reconocían los diferentes gobernadores, reclamando de la autoridad militar

34. BOE n. ${ }^{\circ} 259$ de 16/09/1939, pp. 5.144-5.146. 
de la $8 .^{a}$ Región «una solución de carácter general»35. Aunque los plazos fijados en la normativa se dilataron mucho más de lo previsto, lo cierto es que el Decreto tuvo un eficaz grado de cumplimiento, pero solo en el caso de los locales y terrenos ocupados por el Ejército. Según una comunicación de 18 de febrero de 1941 «Este sistema se ha seguido en esta Región con los locales ocupados por fuerzas o Servicios del Ejército", pero no había podido aplicarse a locales que no estaban ocupados por entidades dependientes del Ministerio del Ejército, en especial las vinculadas al Partido Único, como reconocía, sin ir más lejos, un escrito de fecha 17 de agosto de 1940 en el que el gobernador militar de Lugo aseguraba que FET-JONS no estaba abonando alquiler alguno por los locales que ocupaba en la plaza $^{36}$. Esto permitió que aflorasen numerosos bienes incautados en beneficio de FET-JONS y no pocos casos en los que la normativa se había soslayado, como sucedía cuando un inmueble que había sido requisado por la autoridad militar se entregaba después a una entidad no dependiente del Ejército,

[...] porque entonces era la única Autoridad que podía hacerlo con arreglo al Reglamento de Requisición. Posteriormente los demás locales requisados para organismos no militares, encontraron ordenación jurídica distinta del Ramo de Guerra con el Decreto de 9 de septiembre [...] y a ella deben someterse los organismos que ocupan los locales aceptando la responsabilidad administrativa que establece puesto que, en definitiva, la ocupación y requisa se hizo en beneficio de ellos ${ }^{37}$.

Sin embargo, una cosa fue que los propietarios de bienes sujetos a requisición u ocupación pudiesen recuperarlos o ver reconocido el derecho a percibir una indemnización o alquiler y otra bien distinta que esos pagos se hiciesen con la debida diligencia. Las solicitudes en tal sentido cursadas antes de la entrada en vigor de dicho Decreto recibían de forma invariable la misma lacónica contestación de las autoridades militares: no existía consignación ni orden de pago de alquileres sobre edificios requisados, "pues estas prestaciones habrán de ser valoradas cuando en su día y a tal efecto se constituya la Junta Central de Valoraciones para determinar el pago de las indemnizaciones como proceda ${ }^{38}$. Una vez constituida esta y las Comisiones Provinciales a que se refería la normativa en vigor, los

35. AIMN, SEM n. ${ }^{\circ}$ 4, carpeta "Expedientes de requisa de edificios de la provincia de Lugo (19361945)», 25.

36. AIMN, SEM n. ${ }^{\circ}$ 4, carpeta "Expedientes de requisa de edificios de la provincia de Lugo (19361945)». El jefe provincial del Movimiento, Ramón Ferreiro, negaba tales extremos reconociendo que no se pagaba alquiler en un único caso, pues los demás locales «los ocupa esta organización previo abono de alquileres que viene satisfaciendo desde el primer momento de su ocupación, sin que disfrute ningún otro local que no sea precisamente a título oneroso", lo que desde luego resultaba manifiestamente inexacto.

37. Un ejemplo de los numerosos conflictos y de los perjuicios provocados a los propietarios por esta situación en AIMN, SEM n. ${ }^{\circ} 4$, carpeta "Expedientes de requisa de edificios de la provincia de Lugo (1936-1945).

38. AIMN, SEM n. ${ }^{\circ}$ 4, carpeta "Expedientes de requisa de edificios de la provincia de Lugo (19361945)», 21 
JULIO PRADA RODRÍGUEZ

"TODOS SE CONSIDERAN CON DERECHO A REQUISAR..." REQUISICIONES

E INCAUTACIONES DE BIENES EN GALICIA DURANTE LA GUERRA CIVIL

interesados debían acudir a estas últimas para fijar las cantidades a percibir y recibir la aprobación de la Central para que la Intendencia pudiese tramitar la concesión del crédito necesario. Y aunque diferentes disposiciones establecieron unos plazos perentorios para hacer efectivos los atrasos, lo cierto es que enseguida se revelaron ilusorios obligando a prorrogar durante varios años consecutivos su vigencia sin que se compensase a aquellos por los efectos de la inflación ${ }^{39}$.

Todavía mucho más difícil resultó para los propietarios ver reconocido su derecho a percibir una compensación por los innumerables daños ocasionados en sus inmuebles, ni siquiera en los casos en que podían acreditar el cumplimiento de todos los requisitos que la normativa exigía en tales supuestos. De hecho, un telegrama postal del Inspector General de Fortificaciones y Obras del Ministerio del Ejército de fecha 7 de noviembre de 1939 acabaría por frustrar cualquier esperanza en tal sentido al disponer "que los daños ocasionados en edificios particulares, deben entrar en el concepto genérico de daños producidos por la guerra y ser reparados por sus propietarios con las facilidades que pueda proporcionarles el Instituto de Crédito para la Reconstrucción Nacional» ${ }^{40}$.

\section{Es lógico que todos los españoles [...] CONTRIBUyAN Al SOSTENIMIENTO DE esta SANTA CRUZADa}

Como hemos señalado al principio, no es objeto de este artículo analizar las incautaciones de bienes realizadas al amparo del Decreto $n .{ }^{\circ} 108$ de la JDN de 13 de septiembre de 1936 ni del Decreto de 10 de enero de 1937 y la Orden de la misma fecha que lo desarrollaba. Sin embargo, nuestro estudio no puede dejar de lado las incautaciones sobre particulares y entidades afectas al Frente Popular realizadas con anterioridad a la entrada en vigor de dichas normas y sin otro fundamento que la significación izquierdista de unos y otras. En este sentido, al igual que sucede en otros puntos de la geografía española, los rebeldes no necesitaron ampararse en normativa alguna para llevar a cabo las primeras extorsiones económicas e

39. Cfr. Ley de 9 de marzo de 1940 sobre abono de atrasos procedentes de la etapa de guerra (BOE, n. ${ }^{\circ} 79$ de 19/03/1940, pp. 1.904-1.906; Orden aclaratoria de la misma (BOE, n. ${ }^{\circ} 205$ de 24/07/1941, p. 5.577); Orden del Ministerio de Hacienda sobre la necesidad de dar cumplimiento a lo dispuesto en la mencionada disposición (BOE, n. ${ }^{\circ} 299$ de 26/10/1941, p. 8.353); Orden por la que se dispone se tramiten, informen o resuelvan con la mayor urgencia los expedientes incoados a su amparo (BOE $n$. ${ }^{\circ}$ 310 de 06/11/1941, p. 8.675); y Leyes de Jefatura del Estado prorrogando su vigencia durante 1942 y 1943 (BOE n. ${ }^{\circ} 6$ de 06/01/1942, p. 92 y BOE n. ${ }^{\circ} 1$ de 01/01/1943, p. 3). Tomando como año base 1936 (i=100), el índice de precios al consumo habría ascendido en 1939 hasta el 153,59 y hasta el 245,93 en 1943, lo que significa multiplicar los precios por 2,46 entre ambas fechas (los cálculos a partir del cuadro A1-7 de MAluquer De Motes, Jordi: La inflación en España. Un índice de precios de consumo, 1830-2012, Estudios de Historia Económica, n. ${ }^{\circ}$ 64, Banco de España, 2013, p. 107).

40. AIMN, SEM n. ${ }^{\circ}$, carpeta "Expedientes de requisa de edificios de la provincia de Lugo (19361945)», 21. 
E INCAUTACIONES DE BIENES EN GALICIA DURANTE LA GUERRA CIVIL

incautarse de bienes propiedad de aquellos ${ }^{41}$. Otro tanto ocurrió a la hora de clausurar locales identificados con centros de reunión de "elementos marxistas", muchos de ellos violentados por milicianos o por "personas desconocidas", aunque en Galicia los actos de pillaje que acompañaron en tantos puntos al avance de las tropas no fueron ni mucho menos generalizados, limitándose, por lo general, a una serie de localidades que hubieron de ser tomadas militarmente por las columnas rebeldes. Aun así, el fracaso del golpe de Estado da paso a una situación en la que las diferentes Divisiones Orgánicas decretan por su cuenta, en ausencia de preceptos de carácter general, disposiciones normativas en materia de incautación, ocupación y embargo de bienes. Lo mismo hacen algunos gobernadores civiles, como el de A Coruña, que ordenó la incautación de los locales, muebles, enseres y fondos de todos los centros obreros, incluidos

[...] toda clase de sindicatos y asociaciones que, abierta o encubiertamente, signifiquen representación del socialismo, comunismo, sindicalismo, anarquismo y en general cuantas agrupaciones de este orden formaban el Frente Popular, o simplemente simpatizaban con él, alcanzando también a los Casinos y Centros de recreo, así como a los denominados Ateneos, de las significaciones mencionadas ${ }^{42}$.

Dicha disposición responsabilizaba a los alcaldes de su cumplimiento, pero lo cierto es que al intentar hacerla efectiva aquellos se encontraron con situaciones de lo más diverso. No faltaron ejemplos, como ocurrió con la Casa Sindical de San Pedro de Nos (Oleiros), todavía en fase de construcción, donde sus directivos se habían apoderado de los libros y enseres antes de huir, por lo que cuando el delegado civil, el secretario y la Guardia Civil procedieron a la clausura de las sociedades existentes en la demarcación del puesto solo pudieron incautarse del mencionado edificio. Algo parecido aconteció en Santiago, donde el Delegado de Orden Público confirmaba que los dirigentes de las sociedades obreras afectas al Frente Popular domiciliadas en la Casa del Pueblo habían hecho desaparecer la mayor parte de los enseres, aunque algunas mesas y bancos habían sido incautados para establecer los diferentes Negociados de dicha Delegación. Entre las entidades clausuradas estaban el Centro Radical Autónomo, el Grupo Galeguista y los Sindicatos de Arbitrios Municipales, Carpinteros, Albañiles, Pintores, Transportes Mecánicos, Metalúrgicos y Panaderos, además del Recreo Artístico y la Sociedad de Electricistas, donde se instalarían, respectivamente, los locales de la Sección Femenina de Falange y la CONS. Idéntica suerte corrieron los bienes de la Sociedad Protección Mutua de A Coruña; los de la Protección Social Esteirana (Esteiro-Muros),

41. Cfr. en tal sentido lo ocurre en puntos tan distintos como Burgos (CASTRO, Luis: Capital de la Cruzada. Burgos durante la guerra Civil. Barcelona: Crítica, 2006 pp. 271-272), Córdoba (BARRAGáN Moriana, Antonio: Control social..., op. cit., pp. 43-45), Aragón (Casanova, Julián y Cenarro, Ángela: Pagar las culpas..., op. cit., pp. 42-43) o Álava (Gómez CaLvo, Javier: Matar, purgar, sanar. La represión franquista en Álava. Madrid: Tecnos, 2014, p. 239).

42. Boletín Oficial de la Provincia de A Coruña, 14/04/1936, p. 1. 
JULIO PRADA RODRÍGUEZ

"TODOS SE CONSIDERAN CON DERECHO A REQUISAR..." REQUISICIONES

E INCAUTACIONES DE BIENES EN GALICIA DURANTE LA GUERRA CIVIL

incluidas 681,90 pesetas en metálico, las existencias del comercio de tejidos de su propiedad y los de todas sus filiales; los de los pósitos de pescadores de Louro (Muros), Lira, O Pindo y Carnota; los de la Sociedad Recreativa El Eco del Tea, en este caso para instalación de los Talleres de Mujeres al Servicio de España y de FET de Ponteareas; los del Casino de Monforte, clausurado por el gobernador civil en noviembre de 1936, distribuyendo sus muebles y enseres entre las oficinas y el cuartel de FET y de las JONS, el Instituto de Enseñanza y el Ayuntamiento ${ }^{43}$.

En cambio, la Casa del Pueblo de Betanzos fue ocupada por Falange «desde los comienzos del Movimiento Nacional, ya que fueron los falangistas los que desalojaron por la fuerza a los elementos de la CNT, FAI, Partido Comunista y Partido Socialista que ocupaban dicho inmueble». El local había sido construido a principios de siglo en el n. ${ }^{\circ} 13$ de la Rúa Traviesa gracias a una disposición testamentaria del filántropo brigantino Juan García Naveira, "que lo legó para que con ese título tuvieran los obreros de Betanzos un lugar de reunión y esparcimiento y quizás con fines culturales y benéficos para la clase obrera, toda vez que en aquella época no existía en dicha Ciudad la tan lamentable lucha de clases». Esta disposición hizo que cuando en marzo de 1937 se solicitó la confirmación de su cesión en precario para oficinas y cuartel de milicias fuese informada favorablemente por la Jefatura de Milicias de la División, "siempre que en dicho edificio se instale con preferencia la CONS de la ciudad Brigantina "44.

El Centro de Hijos de Bergondo y sus Contornos fue, asimismo, disuelto por orden militar por ser sus miembros «significados elementos del Frente Popular». Poco después el edificio fue ocupado por la Falange local para alojamiento de sus milicias y demás servicios de la organización. En marzo de 1937, el delegado de la Junta de Mando en Galicia de FE-JONS solicitaba su cesión provisional con el fin de «establecer en él una academia para Jefes de Falange y de Centuria, dotada de toda clase de elementos». El general Franco, que ya había autorizado por esas fechas que "diferentes equipos de personal alemán» al mando de Federico Koethke se hicieran cargo de la instrucción de las milicias falangistas, ordenando que se les diese "cuantas facilidades sea posible para el mejor desempeño de su cometido", acabaría por interesarse personalmente por esta gestión. El 3 de abril de 1937, el gobernador militar de A Coruña informaba al general jefe de la 8. ${ }^{a}$ División que el comandante de la Guardia Civil del puesto de Guísamo había hecho entrega del mencionado edificio a la organización falangista cumplimentando su orden de 22 de $\operatorname{marzo}{ }^{45}$.

43. Todos ellos en AIMN, SEM n. ${ }^{\circ}$ 4, carpeta "Incautaciones", 26; carpeta "Expedientes de requisas y devoluciones de edificios en la provincia de Pontevedra (1936-1945)»; "Expedientes de requisa de edificios de la provincia de Lugo (1936-1945)", 24; "Inventarios y actas de industrias, comercios y otras propiedades incautados a entidades y personas enemigas del Movimiento Nacional», carpeta "Incautaciones", 30 .

44. AIMN, SEM n. ${ }^{\circ}$, carpeta "Incautaciones", 29.

45. AIMN, SEM n. ${ }^{\circ}$ 4, carpeta "Incautaciones», 50. 
E INCAUTACIONES DE BIENES EN GALICIA DURANTE LA GUERRA CIVIL

También fueron muchas las propiedades de particulares que fueron incautadas sin demasiados miramientos, en especial si habían tenido que huir para escapar de la represión o habían sido directamente asesinados. Fue el caso del comerciante ferrolano Guillermo Cedrón Gómez, asesinado el 18 de agosto de 1936, parte de cuyos bienes se repartieron la Sección Femenina, la Jefatura de Policía y la Comisaría. Otro tanto ocurrió con la biblioteca del ex sacerdote y vicepresidente del Comité Municipal de UR de la ciudad departamental Matías Usero ReyTorrente, ejecutado dos días más tarde del anterior, y con la barbería del socialista Miguel Rey Painceiras, muerto a manos de la fuerza pública el 22 de septiembre, cuyos enseres también fueron entregados a Falange. En Noia se incautaron de la fábrica de gaseosas de su alcalde y dirigente local de IR, el comerciante Severino Iglesias Siso, y de cuarenta y cinco fincas rústicas y urbanas de su propiedad, así como de dos casas del patrón de cabotaje Félix Rogelio Veloso y de diversas pertenencias del capitán de Carabineros Francisco Marín Moya y su ordenanza Victoriano Sánchez. Todos ellos habían conseguido huir a Bilbao con alrededor de ocho decenas de republicanos en los vapores de pesca Santa Eulalia y Santa Rosa. Lo mismo sucedió con la casa del alcalde de Vigo Emilio Martínez Garrido, fusilado el 27 de agosto de 1936, situada en el n. 30 de la Avenida de Ramón Nieto, donde se instaló la Compañía de Evacuación Veterinaria de la 82 División y parte de los guardias civiles del puesto de Lavadores así como oficinas y almacén de Piensos y Combustibles del Depósito de Intendencia de Vigo ${ }^{46}$.

En Ribadeo el Juzgado Militar ordenó incautarse de las existencias de diferentes comercios y establecimientos, "por encontrarse sus propietarios huidos con los rebeldes", remitiendo el 9 de octubre de 1936 inventario de los mismos al general jefe de la División "por si considera oportuno a la vista de los citados inventarios, sean enviados algunos de los efectos que en los mismos se encuentran a algún centro militar o en caso contrario si han de quedar los referidos efectos en los establecimientos en que se encuentran actualmente». En su respuesta, el Intendente General señalaba que «es preferible sean vendidos todos estos artículos a los particulares, procurando sacar de ellos el mayor beneficio para el Tesoro y vender con toda urgencia los comestibles que puedan ser de fácil deterioro» ${ }^{47}$. En esta localidad lucense, la Comandancia Militar se instaló en un edificio incautado propiedad del banquero quebrado Manuel Casas, pero en febrero de 1937 el inmueble fue ocupado por orden del general jefe de la División para la instalación de un Hospital. Dado que «de todos los rojos huidos (...) la mayoría habitaban casas alquiladas y los que lo hacían en las que eran de su propiedad, ninguna reunía condiciones de capacidad suficiente», las Comandancias Militar y Naval se trasladaron a una casa propiedad de Isabel Martínez, esposa del ex director general de Enseñanza Primaria con Primo de Rivera Ignacio Suárez Somonte. Cuando este reclamó el

46. AIMN, SEM n. ${ }^{\circ} 4$, carpeta "Incautaciones» y "Expedientes de requisas y devoluciones de edificios en la provincia de Pontevedra (1936-1945)», 20.

47. AIMN, SEM n. ${ }^{\circ} 4$, carpeta "Embargos". 
JULIO PRADA RODRÍGUEZ

"TODOS SE CONSIDERAN CON DERECHO A REQUISAR..." REQUISICIONES

E INCAUTACIONES DE BIENES EN GALICIA DURANTE LA GUERRA CIVIL

inmueble, las autoridades militares ocuparon la casa del vicepresidente local de IR Dionisio Ponceliz Bordes, la única de todos los huidos que «reunía condiciones de capacidad suficiente», cuando ya había sido incautada por el Juzgado Militar de Ribadeo y puesta a disposición de la CPIB $^{48}$. Y así un largo etcétera.

Todas estas incautaciones y las que después se realizarían al amparo de la normativa de responsabilidades civiles no tuvieron otro fundamento que la significación izquierdista, real o presunta, de particulares y entidades. En cambio, las requisas afectaron mucho más en términos cuantitativos a personas y colectividades a las que cabía atribuir una marcada simpatía por los sublevados, lo que no resulta extraño si tenemos en cuenta que, como es lógico, al margen del propio Estado, aristócratas, burgueses, rentistas y, sobre todo, la Iglesia, eran los principales propietarios de inmuebles cuyas características y localización resultaban más adecuados para las necesidades bélicas.

Entre los inmuebles requisados a esa élite social propietaria tan característica de las villas y ciudades gallegas figuraban edificios tan emblemáticos como el Balneario Barreiros de Cuntis, el Hotel Balneario de Mondariz, ambos requisados para Hospital Militar, y el Balneario de Lugo, propiedad de Blanca Neira Pedrosa, viuda de Montenegro, requisado para cuartel de tropas moras; el Cinema Ideal de Pontevedra, requisado para instalar el Regimiento de Infantería n. ${ }^{\circ}$ 57; la finca de la calle Echegaray propiedad de la Sociedad Industrias Gallegas de Pontevedra para instalación de Destacamento de Automóviles; el Frontón Vigués de la calle María Berdiales, propiedad de Juan Vega González, primero destinado a prisión y más tarde a cuartel de milicias de Falange; la Plaza de Toros de Pontevedra para campo de concentración de prisioneros; el Garaje Vigués de García Barbón; el edificio n. 10 de la calle general Franco de Pontevedra propiedad de Dolores Mon Landa y de los herederos del Marqués de Riestra para la Milicia de Falange; varias propiedades de José Luis Iturria Echarte, incluido el Pazo de Agrelo en Redondela, donde se instaló la enfermería de la Legión Cóndor; la Casa Hotel Villa Andrea en Lugo, propiedad de Matías de Oñate y López, Marqués de Ugena, donde se instaló la Enfermería Militar, negándose el gobernador a atender las peticiones de abono de alquileres y desperfectos, "pues es lógico que todos los españoles y especialmente los más pudientes, contribuyan al sostenimiento de esta Santa Cruzada ${ }^{49}$; el bajo de la casa n. ${ }^{\circ} 110$ de la calle del Arenal de Vigo, propiedad de Mercedes Pérez y Pérez de Castro, IX Vizcondesa de Meira, para alojar ganado y personal perteneciente al primer Batallón del 56 Regimiento de Infantería de Montaña; el bajo de n. ${ }^{\circ} 120$ de la Calle Felipe Sánchez propiedad de Vicente Riestra para almacén de pienso para el ganado de los batallones de Infantería de la 82. ${ }^{a}$ División; otros dos pisos de la Calle del Príncipe y la Plaza de Compostela, propiedad, respectivamente, de Marcelino y Julia y Blanca Barreras, para la Legión Cóndor, etc.

48. AIMN, SEM n. ${ }^{\circ}$ 4, carpeta "Incautaciones», 20.

49. La cita en AIMN, SEM n. ${ }^{\circ} 4$, carpeta "Expedientes de requisa de edificios de la provincia de Lugo (1936-1945)», 27. 
Entre las propiedades eclesiásticas requisadas total o parcialmente podemos citar la parte del convento de la Compañía de María de Ciudad Jardín (A Coruña) destinado a enseñanza para ser convertido en Hospital Militar; el monasterio de San Clodio (Leiro, Ourense), requisado en abril de 1939 para alojamiento de prisioneros de guerra; el Seminario de Ourense, utilizado para alojamiento de tropas y para parque de automóviles del Ejército; los colegios de los Hermanos Maristas y los Salesianos de Vigo para albergue de distintos contingentes de tropa movilizados; el monasterio de Oia, incautado por orden telegráfica de Franco al gobernador militar de Pontevedra de 17 de enero de 1939 para que fuese puesto a disposición del Inspector de Campos de Concentración de Prisioneros, etc.

Pero, ¿cuáles fueron las actitudes sociales de la población ante las requisas y las incautaciones? La necesidad de adentrarse en los comportamientos individuales y colectivos, así como en las percepciones, los sentimientos, los discursos y las experiencias de la población ha sido reiteradamente señalada como imprescindible para comprender los procesos de instauración y consolidación de las dictaduras ${ }^{50}$. Dirigir nuestra atención hacia las acciones diarias o las decisiones cotidianas de los ciudadanos nos permite sacar a la luz sus intentos de generar espacios capaces influir en el devenir de los acontecimientos, ya sea para mediatizar ya para analizar cómo sus acciones refuerzan las bases sobre las que se sustenta el poder ${ }^{51}$, como ocurre con quienes se prestan a colaborar de buen grado con la «acción salvadora del glorioso Ejército nacional».

Así, entre quienes ofrecen distintas propiedades a las autoridades sin que medie petición oficial encontramos una amplia representación de los diferentes sectores sociales que apoyaron el golpe. Entre ellos figuran aristócratas como Fernando Osorio de Moscoso y López, duque de Medina de las Torres, y su hermana, la condesa de Carmona, que pusieron a disposición del Ejército los locales de su casa de Vilaboa (Vilagarcía de Arousa) para servicios sanitarios el 10 de marzo de 1937, a los que habría que sumar varias propiedades que tenían ocupadas fuera de Galicia. No faltan tampoco representantes diferentes órdenes religiosas además de las ya reseñadas, caso de los jesuitas, propietarios del Colegio del Pasaje de La Guardia, que lo ofrecieron para instalación de hospitales, «haciendo este nuevo sacrificio que unimos gustosos a los continuos y heroicos de nuestro invencible Ejército, por el triunfo de nuestras ramas y la gloria de España", aunque el edificio y los terrenos colindantes acabarían convirtiéndose en centro de reclusión y, más tarde, en campo de concentración de prisioneros $^{52}$. Ni acaudalados propietarios como el

50. Hernández Burgos, Claudio: «Más allá del consenso y la oposición: las actitudes de la "gente corriente» en regímenes dictatoriales. Una propuesta de análisis desde el régimen franquista", Revista de Estudios Sociales, 50, sep.-dic. 2014, pp. 88-89.

51. Rodríguez Barreira, Óscar J.: "Miseria, consentimientos y disconformidades. Actitudes y prácticas de jóvenes y menores durante la posguerra». En: RoDríguez BArReira, Óscar J. (coord.): El Franquismo desde los márgenes: campesinos, mujeres, delatores, menores... Universidad de AlmeríaUniversitat de Lleida, 2013, p. 167.

52. AIMN, ES. 15.402.05.02205.002. 
"conspicuo vigués" que, antes de embarcar rumbo a América cedió el inmueble de la casa n. ${ }^{\circ} 38$ de la calle del general Queipo de Llano que antes ocupaba la Logia masónica capitalina para alojamiento la Guardia Cívica de la capital.

Pero también hay ejemplos de miembros de la élite burguesa de villas y ciudades de simpatías izquierdistas que intentaron congraciarse de este modo con las autoridades, caso de Didio Rioboo Bustelo, propietario de las Islas de Ons y Onceta, heredadas de su padre Manuel Riobó Guimeráns, un médico enriquecido tras su paso por tierras de Filipinas, que las ofreció para lugar de concentración de detenidos. Didio, que había sido uno de los fundadores de la Agrupación Republicana Radical de Bueu y concejal de esta corporación, acabaría suicidándose en la isla ante el acoso de los falangistas locales. Su esposa y heredera María Antonozzi Palanca, reiteraría el ofrecimiento a su muerte ${ }^{53}$.

Muchos más fueron los que se avinieron a renunciar a cualquier clase de alquiler o compensación, cediendo sus inmuebles de forma gratuita «mientras duren las circunstancias actuales». No obstante, resulta difícil separar aquellos casos en los que esta renuncia se hacía libremente o como resultado de la coacción, con frecuencia nada sutil, de las autoridades militares. Una buena muestra de ellos son los diferentes oficios remitidos a numerosos propietarios pontevedreses a partir de la segunda mitad de 1938 en los que se les informaba que era intención de la Superioridad realizar un reajuste en los arrendamientos a partir de agosto del año anterior, por lo que

[...] le ruego se sirva a la mayor brevedad posible y por escrito, si condona la totalidad o parte de los citados alquileres en favor del Ejército, dando así una plausible muestra de adhesión a nuestro Glorioso Movimiento. Espero de Ud. y de su bien probado patriotismo y desprendimiento una contestación favorable sobre el particular.

Algo más matizados, pero no por ello menos conminatorios, eran los remitidos a los lucenses a instancias de la Jefatura de Requisa del $8^{\circ}$ Cuerpo de Ejército, reclamándoles «se sirva decirme, por escrito y a la mayor brevedad posible, si cede en favor del Ejército el importe de los alquileres o, en caso contrario, fijar el precio mínimo de los mismos, correspondientes al local de su propiedad [...],54.

Los cultivadores de la Alltagsgeschichte en Alemania han tenido el acierto de diferenciar conceptualmente entre widerstand y resistenz, limitando el uso del primer término al terreno de la política formalizada, donde tiene cabida la oposición propiamente dicha, y reservando el segundo para determinadas actitudes que se manifiestan en la esfera de lo $\operatorname{social}^{55}$. Es en este último ámbito donde cobran

53. AIMN, ES. 15.402.05.02205.003.

54. Las citas anteriores en expedientes diversos de las provincias de Pontevedra y Lugo (AIMN, SEM n. ${ }^{\circ}$ ).

55. Broszat, Martin: "A Social and Historical Tipology of the German Opposition to Hitler". En: Large, David Clay (ed.): Contending with Hitler. Varieties os German Resistance in the Third Reich. Cambridge: Cambridge University Press, 1991, pp. 25-34. 
E INCAUTACIONES DE BIENES EN GALICIA DURANTE LA GUERRA CIVIL

vida las que han venido denominándose "resistencias cotidianas", protagonizadas por individuos con recursos sociales y materiales muy escasos y limitados y que por ello habían sido considerados tradicionalmente como como meros sujetos pasivos de la acción del poder. Con su conducta, estos protagonistas subalternos no persiguen provocar una alteración radical en la estructura de dominio hacia la que dirigen sus acciones sino, por lo general, manifestar su oposición hacia un comportamiento o pretensión que supone un ataque más o menos directo a sus intereses o expectativas y, en la medida de sus posibilidades, provocar su rectificación. Por consiguiente, si bien no suponen una muestra de widerstand, sí ponen en evidencia su disconformidad hacia a las demandas del poder, su desacuerdo con su voluntad de hacer prevaler sus exigencias frente a las aspiraciones propias o de su círculo inmediato. Lo ocurrido en el caso de las requisas proporciona abundantes ejemplos del diferente potencial de negociación de los diferentes actores implicados.

Así, frente a quienes se prestaron de buen grado a colaborar estaban los que, por las más diversas razones, mostraron sus reticencias a las pretensiones de requisición emanadas del Ejército o las Milicias. A este respecto, no siempre resulta sencillo colegir de la exteriorización de un desacuerdo con una requisa o una incautación una manifestación de disidencia o de resistencia respecto al régimen en proceso de construcción. Sobre todo porque, como hemos apuntado, en la mayoría de los casos las requisas afectaron a sectores sociales que lejos de haberse opuesto al golpe de Estado colaboraron de forma más o menos voluntaria con el nuevo poder, mientras que las incautaciones afectaron, sobre todo, a personas consideradas desafectas que habían tenido que huir, se encontraban privadas de libertad o, incluso, habían sido ejecutadas.

No había muestra de desafección, por ejemplo, en el escrito remitido al general jefe de la División por la superiora del convento de la Compañía de María de Ciudad Jardín (A Coruña), al que habían requisado los locales destinados a enseñanza para transformarlos en Hospital Militar. De hecho, le recordaba que su comunidad "presta generosamente ocho de sus religiosas [para el cuidado de los enfermos hospitalizados] como tributo y servicio a la Patria en los momentos actuales", pero al mismo tiempo ponía en su conocimiento que debía atender a la formación de trescientas alumnas sin disponer de local adecuado para ello y que su única fuente de sustento eran los ingresos que las monjas percibían por este concepto. Por ello solicitaba que, de mantenerse la requisa, se le cediese la casatorre propiedad del diputado independiente y secretario del Tribunal Supremo Luis Cornide Quiroga «por razón de estar desamueblada y por haber sido procesado su dueño» 56 .

56. El gobernador civil y presidente de la Comisión Provincial de Incautación de Bienes (CPIB) coruñesa informaba al respecto que no veía otro inconveniente en atender a dicha petición que el hecho de estar destinada dicha casa al alojamiento provisional de los españoles evacuados de Francia 
Tampoco podía ser considerado como sospechoso de tibieza en su colaboración con los sublevados el obispo de Ourense, Florencio Cerviño González, que reclamó en repetidas ocasiones el completo desalojo del Seminario, requisado en julio de 1936, ora "para reunir en ejercicios a la tercera parte del clero" ora para garantizar las disposiciones de la Santa Sede que prescribían el riguroso internado de los seminaristas, "y éste se haría imposible sin las dependencias antes referidas". El prelado, en su segundo escrito, fechado en septiembre de 1939, daba gracias a Dios por haber inspirado al Caudillo y al Ejército, pero recordaba que «[...] la guerra ha terminado y necesitamos intensificar la labor de recristianización del pueblo, para la que son indispensables sacerdotes y éstos solamente en los Seminarios podemos formarlos, por lo cual es urgente normalizar la vida de los mismos, paralizada en años anteriores ${ }^{57}$.

Lo mismo ocurría con los ya mencionados Hermanos Maristas de Vigo, lo cual no fue óbice para que exteriorizasen su disgusto por la requisa del colegio para alojamiento de tropas, dando lugar a que el comandante militar de la ciudad olívica contrapusiese su actitud a la de otras órdenes, e incluso particulares, que habían cedido gustosas sus inmuebles para alojamiento de tropas,

[...], sobresaliendo la conducta de los RR.PP. Salesianos, los que desde hace muchos meses vienen cediendo parte del edificio de su residencia para cuartel, a pesar de tener también instalado en el mismo inmueble un colegio de niños. Estos padres quieren a los soldados como si fueran sus hijos, según expresión de ellos, les dan charlas sobre la moral de nuestra Santa Religión, despiden en la estación del ferrocarril a los que sucesivamente marchan a los frentes, su frase constante es que hay que dar a la Patria todo lo que necesite y piden que se les envíen más soldados cuando los locales quedan momentáneamente vacíos en espera de una nueva concentración. [Por el contrario] los HH. Maristas señalar[on] al Estado 2.000 pesetas mensuales como alquiler, durante el tiempo que el colegio fue ocupado por las fuerzas del Ejército, dando ello lugar a que interviniera esta Comandancia de Ingenieros que informó diciendo que la cantidad mensual que se debía considerar apropiada era la de 950 pesetas al mes con una oscilación en más o en menos de un $5 \%{ }^{58}$.

Nonito Pereira Soto, propietario de un ómnibus militarizado, multado por no haberse presentado al regreso de un servicio oficial, atribuía la omisión «a la negligencia del chófer conductor» y no a «un hecho de rebeldía o falta de acatamiento a las disposiciones Militares por cuanto en distintas ocasiones he dejado a beneficio del Glorioso Ejército Español los jornales devengados en servicio de convoyes». El general jefe de la División, a la vez que rechazaba su petición de condonación

que pasaban a zona nacional y que luego eran repartidos por diversos pueblos de la provincia (AIMN, SEM n. ${ }^{\circ} 4$, carpeta "Incautaciones", 21).

57. AIMN, SEM n. ${ }^{\circ}$ 4, carpeta "Expedientes de requisa de edificios de la provincia de Orense (1937-1945)», 4.

58. AIMN, SEM n. ${ }^{\circ}$ 4, carpeta "Expedientes de requisas y devoluciones de edificios en la provincia de Pontevedra (1936-1945)», 38. 
E INCAUTACIONES DE BIENES EN GALICIA DURANTE LA GUERRA CIVIL

de la multa, "por ser impuesta como castigo por falta en el servicio", admitía en cambio «que no aparezca en el correspondiente expediente que lo fue por actos de rebeldía» en atención a las donaciones realizadas. Julio Tomé, dueño de un camión, fue sancionado con doscientas pesetas por haberse ausentado de A Coruña sin autorización, «entorpeciendo con ello el servicio a no poder disponer de dicho coche en el momento en que se consideró preciso", mas no parece que ello se oculte otra manifestación de disconformidad que la derivada de anteponer sus intereses particulares a «los más excelsos de la Patria». La Empresa Lerio (Carballo) no presentó el vehículo exigido a la hora indicada, "siendo causa del retraso sufrido en la salida del convoy", pero ni las propias autoridades militares coligieron de ello que el motivo fuese más allá de una mera negligencia de los administradores.

Ángel García Barcala (A Estrada) ocultó en un garaje un ómnibus de su propiedad todavía sin matricular, desobedeciendo así "los distintos bandos de la Autoridad Militar [en los que] se determinaba había necesidad de dar cuenta de todos los coches de tracción mecánica en sus diferentes estados", exponiéndose a una dura sanción incluso de índole penal, pero su actitud tampoco fue interpretada como un acto de rebeldía u oposición sino como mera falta de colaboración susceptible de ser corregida en vía gubernativa. En cambio, el brigantino Tomás Brea se negó a presentarse al servicio de guardia encomendado "y cuando por el motorista de servicio se le entregó una comunicación estando en una feria sin autorización para ello no obstante haber faltado a la guardia para que firmara el enterado de tenerse que presentar en esta Requisa, se negó a firmar contestando en malas formas" 59 .

Y lo mismo ocurre con ciertos propietarios de inmuebles de Navia de Suarna que se negaron a ofrecerlos para alojamiento de los veintisiete guardias civiles que habían tenido que ser distribuidos en casas particulares por carecer de un local adecuado. El alcalde reconocía que a su llamamiento, «excitándoles al celo de patriotismo y simpatía a las referidas fuerzas que tan excelentes servicios vienen prestando en toda la comarca y que gracias a ellas pueden tener tranquilos sus intereses", habían acudido algunos "no muy pudientes" cuyos inmuebles no resultaban adecuados, "pero que cuando menos demostraron su amor a la causa nacional y a España, mientras que jente (sic) adinerada como D. Ricardo Quindós Fernández, que posee varios edificios de nueva construcción sin habitarlos [...] no ha ofrecido el suyo de grandes dimensiones [...]». Cierto era que este último no había "contribuido en ninguna Suscripción, pues si bien en la de "Pro-Vestuario" contribuyó con 200 pesetas, no fue como donativo voluntario, sino que esta cantidad le fue asignada por la Junta Provincial en el reparto que hizo en la mencionada Villa». Pero en su caso, al igual que en los de los restantes propietarios, más que a una actitud de hostilidad hacia el régimen todo parecía deberse «a que la situación económica del Ayuntamiento no permite pagar alquileres caprichosos que solicitan

59. Todas las citas anteriores en AIMN, SEM n. ${ }^{\circ} 4$, carpeta "Multas impuestas por el jefe de Requisa de Esta Plaza» (1936). 
JULIO PRADA RODRÍGUEZ

"TODOS SE CONSIDERAN CON DERECHO A REQUISAR..." REQUISICIONES

E INCAUTACIONES DE BIENES EN GALICIA DURANTE LA GUERRA CIVIL

algunos propietarios de edificios urbanos enclavados en esta villa, y que consienten tenerlos desalquilados a destinarlos a un fin tan patriótico como umanitario (sic) es el presente caso" ${ }^{60}$.

No menos complejo y variopinto es el catálogo de actitudes sociales que emergen detrás de la reclamación de cantidades pendientes en concepto de alquileres o indemnización por daños ocasionados en los bienes sometidos a requisa. El contratista lucense Manuel Márquez Díaz, afiliado a Falange, al que se le había requisado un edificio destinado a taller y garaje para el Servicio de Recuperación de Automóviles, alegaba como fundamento de su reclamación del alquiler que «se encuentra en una modesta situación económica, por no tener en la actualidad los ingresos necesarios, como en otras ocasiones, por su profesión de contratista de obras, a la cual se dedicaba antes del Glorioso Movimiento Nacional, siendo aquella la principal fuente de utilidades para sostener las atenciones familiares, no contando al presente más que con la renta del local de que hace mención y otros insignificantes recursos o ingresos ${ }^{61}$. Juan de Villavicencio, propietario de un piso en la casa n. ${ }^{\circ} 21$ de Policarpo Sanz requisado para oficinas de la Legión Cóndor en Vigo, al ser conminado para que comunicase si condonaba en todo o en parte la deuda, respondió «que mi modesta posición y posibilidades económicas no me permitían renunciar a los alquileres, pero que en mi deseo de atender la invitación que se me hacía contribuiría con un donativo de quinientas pesetas, para atenciones del Ejército, a descontar de la cantidad que en su día había de percibir por los alquileres devengados» ${ }^{62}$. Paz Cantero Villamil, viuda de Sanjurjo, propietaria de un piso en el n. 79 de la Avenida de García Barbón, requisado para Servicios de Jefatura Administrativa y Comisaría de Guerra, al recibir en parecido tono la petición de cesión o condonación de los alquileres, contestó «que con mucho gusto cedía cien pesetas para nuestros soldados, el resto no lo hacía pues como digo vivimos de lo que renta y por eso esperaba nos abonaran los intereses. Pasaron meses y ni vi que figurara nuestro donativo de 100 pesetas ni abonaban la deuda" ${ }^{63}$. Ni siquiera esgrimió una situación de penuria económica Daniel Fernández Pérez cuando solicitó en enero de 1939 que se le abonasen las mensualidades devengadas desde enero de 1937 por su casa de calle Quiroga Ballesteros n. 3 , cuyo primer piso estaba ocupado por la Jefatura de Transportes Militares desde dicha fecha ${ }^{64}$.

60. AIMN, SEM n. ${ }^{\circ}$ 4, carpeta «Expedientes de requisa de edificios de la provincia de Lugo (19361945)», 26.

61. AIMN, SEM n. ${ }^{\circ}$ 4, carpeta «Expedientes de requisa de edificios de la provincia de Lugo (19361945)", 21

62. AIMN, SEM n. ${ }^{\circ}$ 4, carpeta «Expedientes de requisas y devoluciones de edificios en la provincia de Pontevedra (1936-1945)", 24.

63. AIMN, SEM n. ${ }^{\circ}$ 4, carpeta «Expedientes de requisas y devoluciones de edificios en la provincia de Pontevedra (1936-1945)», 26.

64. AIMN, SEM n. ${ }^{\circ}$, carpeta "Expedientes de requisa de edificios de la provincia de Lugo (19361945)», 5 . 
E INCAUTACIONES DE BIENES EN GALICIA DURANTE LA GUERRA CIVIL

También abundan, sin embargo, los ejemplos en los que, a pesar del ambiente represivo existente, el discurso público deja entrever con claridad actitudes que más que de una imposible resistencia u hostilidad al régimen cabría calificar de críticas o reprobaciones hacia quienes detentaban un poder omnímodo y lo utilizaban de forma arbitraria o, cuando menos, caprichosa. El presidente y el secretario de la Sociedad de Socorros Mutuos de Foz, Eliseo López Veiga y Martín Maañón Couto, se opusieron al intento de requisa del inmueble en el que tenía su sede la entidad para instalar en él la Comandancia de Requetés, alegando que existían en la villa "unas ocho casas desalquiladas, algunas pasa de seis años, [...] que reúnen buenas condiciones para Cuartel de Milicias, [...] por lo que parece poco equitativo que se pretenda ocupar el local de esta Sociedad [...]», obteniendo la comprensión del propio gobernador militar de Lugo ${ }^{65}$. La ourensana María Rodríguez Sanjurjo se negó a aceptar la requisa de dos pisos de un inmueble que la Delegación Sindical de Trabajo pretendía utilizar para centralizar en un mismo inmueble todos los servicios de la Delegación, señalando que «[...] como particular no tienen inconveniente en alquilarlos, pero que para la Organización y sus servicios no quieren hacerlo». La viuda llegó a dirigirse en instancia al general jefe de la División poniendo en su conocimiento que no existía "necesidad o motivo de guerra» que justificase aquella, pero en este caso todo sería en vano y la Delegación de Requisa de la capital acabaría ocupando ambas viviendas ${ }^{66}$. Y es que, como se ha demostrado en otros ámbitos, cuando las exigencias del nuevo poder entraban en conflicto con las necesidades vitales o los meros intereses personales de los individuos y de sus familias, cabía aguardar que estos últimos intentasen hacer prevalecer los propios sobre los considerados ajenos ${ }^{67}$.

Es verdad que las relaciones de poder entre los discursos y las prácticas del Estado y el conjunto de recursos culturales de los que dispone la población para interpretar el mundo que le rodea están sometidos a constantes mutaciones y a cambiantes juegos de equilibrios. Pero no cabe llamarse a engaño: el reparto de papeles entre los diferentes sujetos y el régimen se planteaba en términos de marcada desigualdad y, sobre todo, las posibilidades de negociación de cada uno diferían de forma notable. No solo, desde luego, en función de la categoría o el prestigio social de los implicados, sino fundamentalmente del campo de juego en el que el golpe de Estado hubiese situado a cada uno. Si la superiora, el obispo, los Maristas, Nonito, Ángel o los propietarios de la citada aldea lucense pudieron desplegar un cierto potencial de negociación y hacer visible su disconformidad con las exigencias castrenses se debió a que su identificación con la "causa nacional», fuese

65. AIMN, SEM n. ${ }^{\circ}$ 4, carpeta «Expedientes de requisa de edificios de la provincia de Lugo (19361945)», 21.

66. AIMN, SEM n. ${ }^{\circ}$ 4, carpeta "Expedientes de requisa de edificios de la provincia de Orense (1937-1945)», 3.

67. Murillo, Irene: "Ni moral, ni justo, ni legal, ni humano". Resistencias civiles al franquismo". En: Casanova, Julián y Cenarro, Ángela (eds.): Pagar las culpas..., op. cit., p. 241. 
JULIO PRADA RODRÍGUEZ

"TODOS SE CONSIDERAN CON DERECHO A REQUISAR..." REQUISICIONES

E INCAUTACIONES DE BIENES EN GALICIA DURANTE LA GUERRA CIVIL

real o apócrifa, no les hacía aparecer como sospechosos de «actos de rebeldía» sino como meros negligentes, descuidados o si acaso faltos del necesario entusiasmo como para sacrificar sus intereses por aquella. En cambio, la más tenue reticencia, la más liviana tibieza en quienes habían sido marcados como desafectos solía ser interpretada como una muestra de desafección destinada a ser corregida con la mayor severidad, por lo que la posibilidad de exteriorizar el desacuerdo y salir de ello indemne resultaba casi ilusoria.

\section{CONCLUSIONES}

El amplio catálogo de actuaciones que conforman el complejo entramado de la represión económica durante la guerra civil y el franquismo exige extremar las precauciones para no confundir prácticas en apariencia muy semejantes, pero que constituyen realidades bien diferentes y en absoluto homologables. Las requisas llevadas a cabo por las autoridades militares durante la guerra civil se integran dentro de esa gigantesca maquinaria burocrática y de extorsión creada por los rebeldes para intentar responder con eficacia a las necesidades derivadas del fracaso del golpe de Estado y su transformación en guerra civil. Pero no constituyen más novedad que la exigencia de llevarlas a cabo en unas circunstancias en las que asegurar las «necesidades del servicio» primó sobre otras consideraciones de índole administrativa o formalista. Esto explica la gran cantidad de bienes muebles e inmuebles que durante los primeros meses fueron requisados por diversas autoridades sin ajustarse a los procedimientos previstos en la prolija normativa heredada y a las propias disposiciones dictadas, primero, por la Junta de Defensa Nacional y, más tarde, por los organismos que la sustituyeron.

Esas perentorias urgencias y la existencia de un cierto policentrismo germinal, con numerosos comandantes militares e incluso Jefaturas de Milicias arrogándose el derecho de requisición, favorecieron la multiplicación de situaciones en las que los abusos fueron ciertamente frecuentes. Pero al margen de las requisas no regladas ni legalizables -en realidad auténticos expolios practicados por milicianos que actuaban sin mandato de la autoridad militar, pero frecuentemente con su tolerancia inicial-, que no fueron objeto de esta aportación y presentan una problemática bien distinta, lo cierto es que en este capítulo no puede hablarse de una situación generalizada de descontrol en la retaguardia gallega. Ni la Intendencia Militar de la División dejó de funcionar -es muy significativo que sus Juntas Técnica y Económica se reuniesen con normalidad solo unos días después de declarado el estado de guerra- ni se prescindió por completo de las formalidades de rigor, incluso antes de que el Estado campamental del que hablaba Ramón Serrano Suñer fuese imponiendo progresivamente su autoridad.

Las incautaciones de bienes de particulares y entidades políticas y sociales afectas al Frente Popular realizadas antes de la entrada en vigor del Decreto n. ${ }^{\circ} 108$ y del posterior Decreto Ley n. ${ }^{0} 157$ y la Orden que lo desarrollaba coinciden con las requisas en que su destino final fue el de satisfacer las necesidades bélicas y de 
sostenimiento de la retaguardia. Pero difieren tanto por su significado como por el procedimiento para hacerlas efectivas y, naturalmente, por quienes fueron los sujetos pasivos de unas y otras. Mientras estas últimas estaban configuradas como una forma de ocupación temporal -excepción hecha de las cosas consumiblesque si bien daba derecho a una indemnización se diferenciaba de otras figuras expropiatorias tanto por su causa legitimadora -las necesidades bélicas- como por el método expeditivo mediante el cual los habilitados para practicarlas adquirían su posesión, las primeras carecían de otra referencia normativa que los bandos de guerra y la consideración como "enemigos» de las víctimas. Muy pronto este vacío va a ser suplido por diferentes autoridades, sobre todo comandantes militares, que lo mismo decretan por su cuenta la clausura de centros obreros que disponen la incautación de las propiedades de «extremistas» huidos o en prisión.

La complejidad de las actitudes sociales respecto al franquismo se pone también en evidencia en el ámbito que nos ocupa. Como en tantos otros apartados, también aquí es posible descubrir una amplia paleta de tonalidades que abarca desde las inquebrantables adhesiones hasta las formas de resistencia de baja intensidad. Y, asimismo, es posible comprobar cómo esas actitudes no definen de forma rígida e inamovible a unos grupos sociales concretos sino que muchas veces resultan transversales, además de dinámicas y fluctuantes en el tiempo, incluso en un mismo sujeto. El modo en el que la población reaccionó ante las requisas y las incautaciones durante la guerra civil, a pesar de lo excepcional de unas circunstancias en las que la menor muestra de tibieza corría el riesgo de ser interpretada como desafección y dar lugar a la exigencia de las más «severas responsabilidades», nos permite rechazar la idea de que en medio de la polarización resultante de la contienda bélica no pudieran abrirse espacios en los que los individuos fuesen capaces de desplegar su potencial de negociación sobre cuestiones que para ellos resultaban fundamentales. Pero este resultó ciertamente limitado y, sobre todo, difería de forma radical en función de la calificación que cada uno mereciese para los detentadores del poder.

Es verdad que para la mayoría no cabía más alternativa que adaptarse a la situación creada por el golpe de Estado y la guerra civil, al nuevo poder emergente y a las formas en las que este tenía de hacerse patente en cada parcela de la vida cotidiana de los individuos. Pero incluso en este contexto tan desfavorable, los individuos nunca carecen por completo de recursos que les permitan interactuar con el mundo que les rodea. Y, por consiguiente, dentro de los estrechos márgenes que aquel permitía, tratan de sortear, como demostramos, aquellas demandas que les resultan más gravosas, unas veces recurriendo a la ocultación y al fingimiento, otras intentando retrasar o diferir su desempeño, cuando no directamente entorpeciendo u obstaculizando su cumplimiento. Negociar en el marco de los reducidos límites de la tolerancia que estaba dispuesto a admitir el régimen era la única alternativa viable para quienes, de una forma u otra, se encontraban ante la ineludible tesitura de confrontar sus intereses con los de aquel. 